rằng ảnh chụp bằng điện thoại di động có thể là công cụ tin cậy để chẩn đoán sâu răng.Tuy vậy, chúng tôi đưa ra kết luận giống như các nghiên cứu khác trên thế giới rằng phương pháp chẩn đoán sâu răng qua ảnh chụp có độ đặc hiệu cao, độ nhạy chấp nhận được so với quy định của tổ chức y tế thế giới và phù hợp để làm phương pháp chẩn đoán ở cộng đồng. Hơn nữa, phương pháp này sử dụng công cụ phổ biến, có sẵn, gần gũi với mọi người, có tiềm năng phố cập sử dụng trong gia đình làm công cụ khám sàng lọc ban đầu. Cuối cùng, phương pháp tạo ra một cơ sở dữ liệu to lớn để lưu trữ, làm công cư dạy học, thuận tiện tham khảo ý kiến chuyên môn của các chuyên gia.

\section{KẾT LUÂN}

Qua nghiên cứuthực trạng bênh sâu răng qua khám lâm sàng trên 250 sinh viên năm thứ nhất ngành điều dưỡng, trường $\mathrm{CaO}$ đẳng $\mathrm{Y}$ tế Hà Đông, năm học 2019-2020cho thây tỷ lệ sinh viên sâu răng nhóm răng hàm lớn tương đối cao 93,2\% qua khám lâm sàng. Sâu răng được phát hiện ở mặt nhai nhiều hơn mặt ngoài. Độ nhạy và độ đặc hiệu của chẩn đoán sâu răng nhóm răng hàm lớn tương đối tốt. Mặt nhai có độ nhạy của chẩn đoán sâu răng nhóm răng hàm lớn cao hơn mặt ngoài. Độ chính xác đều lớn hơn 80\%.

\section{TÀI LIÊU THAM KHẢO}

1. Trân Văn Trường, Trịnh Đình Hải;, Điều tra sức khỏe răng miệng toàn quốc. Nhà xuất bản $Y$ học, 2002: p. 23-70.

2. Boye, U., et al., Comparison of photographic and visual assessment of occlusal caries with histology as the reference standard. BMC Oral Health, 2012. 12: p. 10.

3. Bottenberg, P., et al., Comparison of occlusal caries detection using the ICDAS criteria on extracted teeth or their photographs. 2016. 16(1): p. 93.

4. Underwood, B., J. Birdsall, and E.J.B.d.j. Kay, The use of a mobile app to motivate evidencebased oral hygiene behaviour. 2015. 219(4): p. E2.

5. Estai, M., et al., Comparison of a smartphonebased photographic method with face-to-face caries assessment: a mobile teledentistry model. 2017. 23(5): p. 435-440.

6. Nguyê̂n Thi Thu Hà., Thực trang sâu răng, nhu cầu điêu trị và một số yếu tố ảnh hưởng tới bệnh sâu răng của sinh viên năm thứ nhất, trường Đại học Y Hà Nội, năm học 2015-2016. 2016, Đại học Y Hà Nội.

7. Estai, M., et al., The efficacy of remote screening for dental caries by mid-level dental providers using a mobile teledentistry model. Community Dent Oral Epidemiol, 2016. 44(5): p. 435-41.

8. Werle, S.B., et al., Photography in pediatric dentistry: basis and applications. 2015.

\title{
KẾT QUẢ ĐIỀU TRI UNG THƯ PHỔI KHÔNG TẾ BÀO NHỎ CÓ ĐộT BIẾN EGFR HIỂM BẰNG THUỐC ỨC CHẾ TYROSINE KINASE (TKIs) THẾ HỆ 1 VÀ 2
}

Nguyễn Thị Thái Hòa*

\section{TÓM TẮT}

Các đôt biến hiếm và đột biến kép chiếm tỷ lệ dưới $10 \%$ trong số ung thư phổi có đột biến EGFR, thường có đáp ứng với TKIs thế hệ 1 kém hơn các đột biến thường gặp. Mục tiêu: Nhận xét một số đặc điểm bệnh học của ung thư phổi không tế bào nhỏ giai đọan tiển xa có đột biến EGFR hiếm và đánh giá tỷ lệ đáp ứng của nhóm bệnh nhân này với TKIs thế hệ 1 và 2. Đối tượng và phương pháp: Mô tả hồi cứu 29 bệnh nhân ung thư phổi không tế bào nhỏ giai IV có đột biến EGFR hiếm hoặc kép Kết quả: Các vị trí đột biến hiếm gặp trong nghiên cứu là: G719X, S768I L861Q. Đột biến kép 7/29 bệnh nhân (24\%). Tỷ lế

\section{*Bênh viện K}

Chiu trách nhiẹm chính: Nguyễn Thị Thái Hòa Email: bshoabvk@gmail.com

Ngày nhận bài: 25/2/2021

Ngày phản biện khoa hoc: 8/3/2021

Ngày duyệt bài: 31/3/2021 đáp ứng và kiểm soát bệnh với TKIs thế hê 1 là $41,7 \%$ và $66,7 \%$; với TKİs thế hệ 2 là $82,3 \%$ và 88 ,2\% Kết luận: TKI thế hệ 1 và 2 có hiệu quả ở một số đột biến EGFR hiếm và kép, TKIs thế hệ 2 có tỷ lệ đáp ứng và kiểm soát bênh cao hơn TKIs thế hê 1 .

Tư khóa: Ung thư phổi không tế bào nhỏ, đột biến EGFR, thuốc ức chế Tyrosine Kinase.

\section{SUMMARY \\ TREATMENT RESULTS OF ADVANCED NON SMALL-CELL LUNG CANCER HARBOURING UNCOMMON EGFR MUTATIONS BY FIRST AND SECOND GENERATION TYROSINE KINASE INHIBITORS}

Rare mutations and double mutations account for less than $10 \%$ of lung cancers with EGFR mutations, often with a worse response to 1st generation TKIs than common mutations. Objective: To review some pathological features of advanced non-small cell lung cancer with rare EGFR mutation and to evaluate the response rate of this group of patients to 1st and 2 nd generation TKIs. Subjects and methods: 
Retrospective description of 29 patients with stage IV non-small cell lung cancer with rare or double EGFR mutation Results: The rare mutation sites in the study were: G719X mutation, S768I mutation, L861Q mutation. Double mutations $7 / 29$ patients (24\%). The response rate and disease control with 1st generation TKIs was $41.7 \%$ and $66.7 \%$; with 2 nd generation TKIs $82.3 \%$ and $88.2 \%$. Conclusion: 1 st and 2 nd generation TKIs are effective in rare and double EGFR mutations, and 2nd generation TKIs have a higher rate of disease response and control than 1st generation TKIs

Keywords: Non-small-cell lung cancer, EGFR mutations, Tyrosine Kinase Inhibitors.

\section{I. ĐẶT VẤN ĐỀ}

Ung thư phổi không tế bào nhỏ (UTPKTBN) chiếm tỷ lệ $80-85 \%$ các loại ung thư phổi. Với những hiểu biết mới về con đường dẩn truyền tín hiệu tế bào, điều trị UTPKTBN giai đoạn tiến xa có rất nhiều tiến bộ trong thời gian gần đây, thay đổi tiên lượng đáng kể cho nhóm bệnh nhân này. Đột biến EGFR (Epidermal Growth Factor Receptor) chiếm tỷ lệ 30-40\% trong sô bệnh nhân Việt Nam [1]. Đột biến EGFR thường xảy ra ở exon từ 18 đến 21 của gen EGFR. Trong đó, đột biến mất đoạn ở exon 19 và đột biến thay thế L858R ở exon 21 chiếm chủ yếu (85\%$90 \%)$, điều trị bằng EGFR Tyrosine Kinase inhibitors (TKIs) có cải thiện hơn so với hóa trị tỉ lệ đáp ứng (ORR) $(71,2 \%$ với $47,3 \%, P<0,001)$ và sống thêm không tiến triển (PFS) (10,9 tháng với 7,4 tháng, $P<0,001$ ) [2]. Các đột biến gen EGFR hiếm là các đột biến có tỷ lệ gặp thấp 8\%$12,4 \%$, có tỉ lệ đáp ứng với TKIs và PFS thấp hơn so với các đột biến thường gặp (trung vị PFS 5,0 tháng, ORR 48,4\%)[3,4]. TKI thế hệ 2 Afatinib có tại Việt Nam từ cuối 2018 và trở thành là lựa chọn tối ưu cho các bệnh nhân có đột biến hiếm. Trước thời điểm đó, các bệnh nhân có đột biến hiếm được điều trị bằng TKI thế hệ 1 . Cho tới nay, chưa có đánh giá nào tại Việt Nam về kết quả điều trị của nhóm bệnh nhân này. Vì vậy, chúng tôi tiến hành đề tài này nhằm hai mục tiêu:

- Nhận xét một số đặc điểm bệnh học của ung thư phổi không tế bào nhỏ giai đoạn tiến xa có đột biến EGFR hiếm

- Đánh giá tỷ lệ đáp ứng của nhóm bệnh nhân này với TKIs thế hệ 1 và 2

\section{II. ĐỐI TƯỢNG VÀ PHƯƠNG PHÁP NGHIÊN CỨU}

2.1. Đối tượng nghiên cứu. Bệnh nhân ung thư phổi khổng tế bào nhỏ giai đoạn IV có đột biến hiếm hoặc đột biến kép của gen EGFR điều trị bằng TKIs thế hệ 1 và 2 tại Bệnh viện $\mathrm{K}$ từ $1 / 2017$ đến $6 / 2020$
Tiêu chuẩn chọn:

- Có ít nhất một tổn thương đích đo được

- Điều trị bước 1 bằng TKIs thế hê 1 hoăc 2

- Có kết quả mô bệnh học và xét nghiệm đột biến trên mẫu mô bằng Giải trình tự gen thế hệ mới (NGS) hoặc Real time PCR

Tiêu chuẩn loại trừ: Đột biến Chèn đoạn và T790M nguyên phát ở exon 20 không kèm với một đột biến thường gặp nhạy thuốc

2.2. Phương pháp nghiên cứu: Mô tả cắt ngang, hồi cứu

- Ghi nhận các thông tin về đặc điểm bệnh học

- Điều trị: Bệnh nhân được điêu trị theo một trong 3 thuốc TKIs: Erlotinib 150mg/ ngày; Gefetinib 250 mg/ngày; Afatinib liều khởi trị $30 \mathrm{mg} / \mathrm{ngày}$, tăng giảm liều tùy theo dung nạp của bệnh nhân. Các thuốc được uống đến khi bệnh tiến triển hoặc độc tính không dung nạp được. Xử lý các tác dụng không mong muốn theo hướng dẫn sử dụng.

Nếu bệnh nhân có di căn não và phải phối hợp với xạ trị toàn não hoặc xạ phẫu thì không chọn tổn thương não làm tỏn thương đích

- Đánh giá đáp ứng: Theo tiêu chuẩn RECIST1.1. vào thời điểm 3 tháng từ khi bắt đầu điều trị

2.3. Chọn mẫu: Thuận tiện, thu nhận 29 bệnh nhân.

\section{KẾT QUẢ NGHIÊN CỨU}

\subsection{Một số đặc điểm bệnh học}

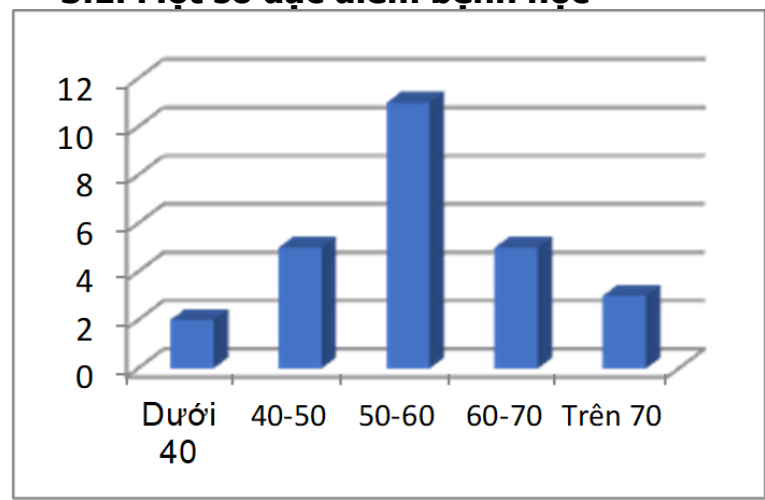

Biểu đồ 3.1. Phân bố tuổi

Nhận xét: Tuổi trung bình 56,2 (31-72). Nhóm 50-60 tuổi chiếm tỷ lệ cao nhất. Giới nam/ nữ $=16 / 13$. Tỷ lệ hút thuốc $16 / 29$ bệnh nhân

Bảng 3.1. Một số đặc điểm bệnh nhân

\begin{tabular}{|c|c|c|c|}
\hline \multicolumn{2}{|c|}{ Tình trạng } & $\begin{array}{c}\text { Số beểnh } \\
\text { nhâ̂n }\end{array}$ & $\begin{array}{c}\text { Tỷ lệ } \\
\text { (\%) }\end{array}$ \\
\hline Chỉ số & ECOG PS 0 & 13 & 44,8 \\
\cline { 2 - 4 } toàn & ECOG PS 1 & 12 & 41,4 \\
\cline { 2 - 4 } trạng & ECOG PS 2 & 4 & 13,8 \\
\hline Vị trí & Phối đối bên & 10 & 34,5 \\
\hline
\end{tabular}




\begin{tabular}{|c|c|c|c|}
\hline \multirow{9}{*}{$\begin{array}{c}\text { di căn } \\
\text { phổ } \\
\text { biến }\end{array}$} & Màng phối & 8 & 27,6 \\
\hline & Não & 7 & 24,1 \\
\hline & Gan & 4 & 13,8 \\
\hline & Xương & 10 & 34,5 \\
\hline & Thượng thận & 6 & 20,7 \\
\hline & & \multicolumn{2}{|c|}{$\begin{array}{r}\text { Exon } 21 \\
\text { (I861Q) }\end{array}$} \\
\hline & & \multicolumn{2}{|c|}{$\begin{array}{l}\text { Exon } 20 \\
\text { (S768I) }\end{array}$} \\
\hline & & \multicolumn{2}{|c|}{$\begin{array}{r}\text { Exon } 18 \\
(\mathrm{G} 719 \mathrm{X})\end{array}$} \\
\hline & & \multicolumn{2}{|c|}{$\begin{array}{c}\text { Exon } 19 \\
\text { (LREA) }\end{array}$} \\
\hline
\end{tabular}

Biểu đồ 3.2. Các loại đột biến

Nhân xét: 7/29 Bênh nhẩn đột biến kép, 10 bênh nhân có đột biến G719X, 7 bênh nhân đôtt biến S768I, 4 bệnh nhân đột biến I861Q, 1 bệnh nhân đôtt biến LREA

\section{2. Đánh giá tỷ lệ đáp ứng}

Bảng 3.2. Tỷ lệ đáp ứng với TKI thế hệ 1 và 2

\begin{tabular}{|c|c|c|c|}
\hline \multirow[b]{2}{*}{$\begin{array}{l}\text { Đáp ứng } \\
\text { điều trị }\end{array}$} & \multicolumn{2}{|c|}{ Loại TKIs } & \multirow[b]{2}{*}{$\begin{array}{l}\text { Tổng } \\
\text { (N/\%) }\end{array}$} \\
\hline & $\begin{array}{c}\text { Thế hệ 1 } \\
(\mathrm{N} / \%)\end{array}$ & $\begin{array}{c}\text { Thế hệ } 2 \\
(\mathrm{~N} / \%)\end{array}$ & \\
\hline Hoàn toàn & $0(0)$ & $0(0)$ & $0(0)$ \\
\hline Một phân & $5(41,7)$ & $14(82,3)$ & $19(65,5)$ \\
\hline $\begin{array}{l}\text { Bệnh ốn } \\
\text { định }\end{array}$ & $3(25,0)$ & $1(5,9)$ & $4(13,8)$ \\
\hline $\begin{array}{l}\text { Bệnh tiến } \\
\text { triển }\end{array}$ & $4(33,3)$ & $2(11,8)$ & $0,7)$ \\
\hline Tống & $12(100,0)$ & 17(100, & $29(100$, \\
\hline
\end{tabular}

Nhân xét: Tỷ lệ đáp ứng 65,5\%; tỷ lệ kiếm soát bệnh $79,3 \%$. Tỷ lệ đáp ứng và kiểm soát bệnh của TKI thế hệ 1 và 2 tương ứng là $41,7 \%$ và $66,7 \%$ so với $82,3 \%$ và $88,2 \%$.

Bảng 3.3. Tỷ lệ đáp ứng với từng loại đột biến \begin{tabular}{|l|l|l|}
\hline Vị trí đột biến & TKI Thế hệ 2 & TKI thế hệ 1 \\
\hline
\end{tabular}

\begin{tabular}{|c|c|c|c|c|}
\hline & $\begin{array}{c}\text { Đán } \\
\text { ứng }\end{array}$ & $\begin{array}{c}\text { Khổng } \\
\text { ĐƯ }\end{array}$ & $\begin{array}{c}\text { Đáp } \\
\text { ứng }\end{array}$ & $\begin{array}{c}\text { Khống } \\
\text { ĐƯ }\end{array}$ \\
\hline Exon 21 I816Q & 3 & 0 & 1 & 0 \\
\hline Exon 20 S768I & 5 & 1 & 1 & 0 \\
\hline Exon 18 G719X & 5 & 2 & 1 & 2 \\
\hline Exon 19 (LREA) & 0 & 0 & 0 & 1 \\
\hline Kép & 1 & 0 & 2 & 4 \\
\hline Tống & $\mathbf{1 4}$ & $\mathbf{3}$ & $\mathbf{5}$ & $\mathbf{7}$ \\
\hline
\end{tabular}

\section{BÀN LUÂ̂N}

Nghiên cứu của chúng tôi thu nhận được 29 bệnh nhân. Tuổi mắc bệnh trung bình là 56,2 , nam/nữ là $16 / 13$, phần lớn các bệnh nhân có chỉ số toàn trạng PS 0,1 . Vị trí di căn hay gặp nhất là phổi đối bên và xương đều chiếm tỷ lệ 34,5\%. Các vị trí đột biến hiếm gặp trong nghiên cứu là:
10 bệnh nhân có đột biến G719X, 7 bệnh nhân đột biến S768I, 4 bệnh nhân đột biến L861Q, 1 bệnh nhân đột biến LREA. Ngoài ra, nghiên cứu của chúng tối cũng thu nhâan đước $7 / 29$ bênh nhân có đột biến kép. Trong nghiên cứu của James $\mathrm{C}-\mathrm{H}$ Yang và $\mathrm{CS}$, trong số 600 bệnh nhân có đột biến EGFR ở 3 nghiên cứu LUXLUNG 2, 3, 6 tỷ lệ bệnh nhân đột biến hiếm là 12\%. Trong số này, các đột biến hiếm hay gặp là đột biến G719X (18/75 bệnh nhân), L861Q (16/75 bệnh nhân); S768I (9/75 bệnh nhân)[5]. Kết quả này tương tự như trong nghiên cứu của chúng tôi.

Về tỳ lệ đáp ứng, afatinib được cho là TKIs có hiệu quả cao nhất đối với đột biến hiếm và đột biến kép. Trong nghiên cứu của James $\mathrm{C}-\mathrm{H}$ Yang, tỷ lệ đáp ứng của với afatinib các bệnh nhân nhóm 1 (bao gồm đột biến hiếm hoặc kép exon 18-21 loại trừ T790M và đột biến chèn đoan exon 20) là $71,1 \%$; sống thêm không tiến triển (PFS) và sống thêm toàn bộ (OS) đạt được rất tốt, lần lượt là 10,7 tháng và 19,4 tháng, ngang với kết quả điều trị đột biến thường gặp bằng TKIs thế hệ 1 [2]. Nghiên cứu của chúng tôi cũng cho một kết quả tương tự với tỷ lệ đáp ứng của afatinib là $82,3 \%$. Đáp ứng của TKIs thế hệ 1 thấp hơn so với TKIs thế hệ 2 trong nhóm bệnh nhân này. Theo tác giả Shen YC, trong 51 bệnh nhân có đột biến hiếm (loại trừ đột biến chèn đoạn exon 20, tỷ lệ đáp ứng với TKIs thế hệ 1 và 2 lần lượt là $50 \%$ và $62,5 \%(p=0,35)$, khác biệt về PFS rất rõ rệt (3,6 tháng so với 11 tháng với $p=0,03$ [ [6]. Cũng theo tác giả này, đột biến kép cho kết quả điều trị khá tốt với cả hai thế hệ TKIs. Trong nghiên cứu của chúng tôi, tỷ lệ đáp ứng với TKI thế hệ 2 cũng cao hơn so với TKI thế hê 1 , có 1 bênh nhân có đột biến kép điều trị thế hể 2 có đáp ứng, trong khi chỉ có $2 / 6$ bệnh nhân đột biến kép đáp ứng với TKI thế hệ 1. Theo tác giả Barbara Klughammer, hai đột biến có kết quả cao với TKI thế hệ 1 là đột biển G719 ở exon 18 và S768I ở exon 20 [7]. Trong nghiên cứu của chúng tôi hai đột biến này tỷ lệ đáp ứng rất tốt với TKI thế hệ 2 , lần lượt $5 / 7$ và $5 / 6$ bệnh nhân có đáp ứng.

\section{KẾT LUẬN}

Nghiên cứu 29 bệnh nhân ung thư phổi không tế bào nhỏ giai đoạn tiến xa có đột biến EGFR hiếm hoặc kép, điều trị bằng TKIs thế hệ 1 và 2 chúng tôi rút ra những kết luận sau:

- Tuổi trung bình là 56,2, nam/nữ là 16/13

- Các vị trí đột biến hiếm gặp trong nghiên cứu là G719X, S768I, biến L861Q. Đột biến kép 7/29 bệnh nhân (24\%). 
- Tỷ lệ đáp ứng và kiểm soát bệnh với TKIs thế hệ 1 là $41,7 \%$ và $66,7 \%$

- Tỷ lệ đáp ứng và kiểm soát bệnh với TKIs thế hệ 2 là $82,3 \%$ và $88,2 \%$

\section{TÀI LIÊU THAM KHẢO}

1. Anh Thu Huynh Dang, et al (2020). "Actionable Mutation Profles of non-Small cell Lung cancer patients from Vietnamese population", Scientific Reports, 10:2707 https:// doi.org/ 10.1038/s41598-020-59744-3 5

2. T. S. Mok, Y. L. Wu, S. Thongprasert et al (2009). "Gefitinib or carboplatin-paclitaxel in pulmonary adenocarcinoma". N Engl J Med, 361 (10), 947-957.

3. J. Y. Wu, C. J. Yu, Y. C. Chang et al (2011). "Effectiveness of tyrosine kinase inhibitors on "uncommon" epidermal growth factor receptor mutations of unknown clinical significance in nonsmall cell lung cancer". Clin Cancer Res, 17 (11), 3812-3821.

4. J. C. Yang, M. Schuler, S. Popat et al (2020).
"Afatinib for the Treatment of NSCLC Harboring Uncommon EGFR Mutations: A Database of 693 Cases". J Thorac Oncol, 15 (5), 803-815.

5. James C-H Yang, Lecia V Sequist, Sarayut Lucien Geater (2015). "Clinical activity of afatinib in patients with advanced non-small-cell lung cancer harbouring uncommon EGFR mutations: a combined post-hoc analysis of LUX-Lung 2, LUXLung 3, and LUX-Lung 6". Lancet Oncology, VOLUME 16, ISSUE 7, P830-838, JULY 01, 2015.

6. Shen YC, Guan -Chin Tseng, Chih - Jeh Tu et al (2017). "Comparing the effects of afatinib with gefitinib or Erlotinib in patients with advancedstage lung adenocarcinoma harboring non-classical epidermal growth factor receptor mutations". Lung Cancer, 2017Aug; 110:56-62.

7. Barbara Klughammer, Wolfram Brugger, Federico Cappuzzo, et all (2016), Examining Treatment Outcomes with Erlotinib in Patients with Advanced Non-Small Cell Lung Cancer Whose Tumors Harbor Uncommon EGFR Mutations, Journal of Thoracic Oncology, Vol. 11 No. 4: 545-555.

\title{
ĐÁNH GIÁ HIÊU QUẢ SÁT KHUẨN CỦA DUNG DICH CHLORHEXIDINE 2\% TRÊN TỬ RĂNG HOẠI TỬ BẰNG KỸ THUẨT REAL - TIME PCR
}

\author{
Dương Thu Hương*, Huỳnh Phạm Thảo Nguyên*, \\ Huỳnh Công Nhật Nam*, Nguyễn Thu Thủy*, Phạm Văn Khoa*
}

\section{TÓM TẮT}

Mục tiêu: Đánh giá hiệu quả sát khuẩn của dung dịch chlorhexidine $2 \%$ trên tủy răng hoại tử bằng kỹ thuật Real - time PCR. Vật liệu và phương pháp: Nghiên cứu thử nghiệm lẩm sàng, đánh giá lượng vi khuẩn trên 32 răng hoại tử tủy ở giai đoạn trước và sau khi điều trị với dung dịch $\mathrm{CHX} 2 \%$ bằng kỹ thuật real - time PCR. Kết quả: Lượng vi khuẩn còn lại trên 32 răng hoại tử tủy sau khi điều trị bằng dung dịch $\mathrm{CHX} 2 \%$ thấp hơn lượng vi khuẩn ban đầu có ý nghĩa thống kê $(p<0,001)$. Trung vị lượng vi khuẩn ban đầu là $1770 \times 103$ DU và sau khi điều trị chỉ còn $16,55 \times 103$ DU.Số lượng vi khuẩn trên các nhóm răng trước, răng cối nhỏ và răng cối lớn hoại tử tủy đều giảm có ý nghĩa thống kê sau được điều trị với dung dịch $\mathrm{CHX}$ $2 \%(p<0,05)$, lượng vi khuẩn còn lại sau điều trị cũng không khác biệt ở cả ba nhóm răng $(p>0,05)$. Số lượng vi khuẩn ở các răng hoại tử tủy có lộ tủy và không lộ tủy đều giảm có ý nghĩa sau khi điều trị với dung dịch $\mathrm{CHX} 2 \%(p<0,001)$, lượng vi khuẩn còn lại

*Đại Hoc Y Dước TP HCM.

Chịu trách nhiệm chính: Dương Thu Hương

Email:dthuong@ump.edu.vn

Ngày nhận bài: 19/2/2021

Ngày phẩn biện khoa học: 19/3/2021

Ngày duyệt bài: 8/4/2021 ở nhóm lộ tủy cao hơn nhóm không lộ tủy có ý nghĩa thống kê $(p<0,05)$. Kết luận: Dung dịch $\mathrm{CHX} 2 \%$ cho hiệu quả diệt khuẩn tốt trên tất cả các răng hoại tử tủy, kể cả nhóm răng hoại tử tủy có lộ tủy và không lộ tủy.

Từ khóa: Chlorhexidine, natri hypoclorite, nhiễm khuẩn nội nha, real-time PCR

\section{SUMMARY}

EVALUATE THE ANTIMICROBIAL EFFICACY OF 2\% CHLORHEXIDINE SOLUTION ON NECROTIC PULP BY REAL - TIME PCR

Objectives: To evaluate clinical antimicrobial efficacy of $2 \% \mathrm{CHX}$ solution on human root canals containing necrotic pulp tissue by real-time PCR. Materials and methods:Clinical trial study, evaluate the bacteria amount by real - time PCR on 32 root canals containing necrotic pulp before and after being irrigated with 2\% CHX solution. Results:The amount of bacteria remained in root canals after treatment was significantly lower than the initial bacterial load $(p<0.001)$. The amount of baseline bacteria was $1770 \times 103$ DU and after treatment was only $16.55 \times 103$ DU. Bacteria on the anterior teeth, premolar and molar teeth all decreased significantly after being treated with $2 \% \mathrm{CHX}$ solution $(\mathrm{p}<0.05)$, there was no difference about the remaining bacteria after treatment in three teeth groups $(p>0.05)$. The amount of bacteria in the necrotic pulp with and without exposing pulp chamber both decreased 